\title{
NASKHDALAM AL-QUR'AN
}

\section{(Al-Nāsikh wa al-Mansūkh)}

\author{
Oleh: Akmal ${ }^{1}$ \\ ${ }^{1}$ Institut Agama Islam Muhammadiyah Sinjai, \\ Jl.Sultan Hasanuddin. No. 20 Balangnipa, Sinjai
}

\begin{abstract}
$* * *$
Abstrak

Al-Quran adalah pedoman muslim yang diturunkan dengan menggunakan bahasa Arab melalui nabi Muhammad Saw. Nasikh dalam Ulumul Qur'an diartikan sebagai sesuatu yang membatalkan, menghapus, memindahkan, maka Mansukh diartikan sesuatu yang dibatalkan, dihapus dan dipindahkan. Sedang pengertian secara terminologi adalah mengangkatkan hukum syara' dengan perintah atau khitab Allah yang datang kemudian dari padanya. Dengan mengetahui adanya naskh dalam al-Qur'an maka akan mengasah keimanan akan kemukjizatan al-Qur'an bahwa dibalik pertentangan (meskipun tidak ada pertentangan) itu Allah Maha Mengetahui apa yang terbaik bagi hamba-Nya. Pada tulisan ini penulis membahas tentang Naskh dalam al-Quran yaitu; (1) Naskh dan perbedaan pendapat tentangnya (2) ruang lingkup dan syarat-syarat naskh (3) jenis-jenis naskh dan hikmahnya. Sehingga dalam proses penggalian dan pendalaman terhadap kitab suci tersebut ada beberapa hal yang yang berhubungan dengannya antara lain dari segi nuzul al-Qur'an, asbab al-nuzul, jam' al-Qur'an wa tartibuhu, surah-surah makkiyah dan madaniyah, muhkam mutasyabih, nasikh dan mansukh serta masih banyak lagi ilmu-ilmu lainnya. sehingga para ulama tafsir dan ushul membuat kesepakatan pembatasan tentang ketentuan pendapat penerimaan atau penolakan adanya kemungkinan naskh mansukh dalam al-Qur'an, termasuk di dalamnya penetapan asas untuk menentukan adanya naskh mansukh serta hikmah yang ada terhadap adanya naskh mansukh pada ayat tidak bisa di-naskh dengan ra'y, ijtihad dan tafsiran tanpa menukil dalil dan penggalian.
\end{abstract}

Kata Kunci: Naskh, al-Qur'an

\section{PENDAHULUAN}

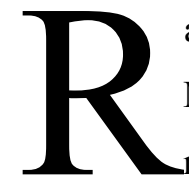

asulullah Saw. beserta rasul dari agama samāwi lainnya merupakan pembawa risalah dari Maha Pencipta yang bertujuan untuk memperbaiki aqidah dan ibadah umat manusia, keyakinan dan hubungan antar sesama. Hal ini menuntut adanya pedoman, khususnya bagi Rasulullah Muhammad saw. dan umatnya yang disebut dengan al-Qur'an. Dalam kaitannya dengan ini Allah mengisyaratkan melalui firman-Nya dalam QS. Al-Furqān/25:1

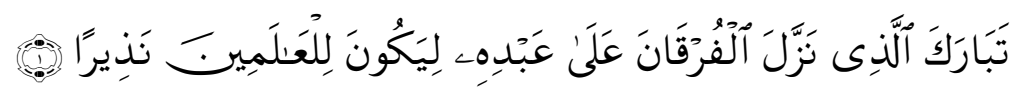

Terjemahnya:

"Maha suci Allah yang telah menurunkan Al-Furqaan (al-Quran) kepada hamba-Nya, agar Dia menjadi pemberi peringatan kepada seluruh alam".

Pada ayat lain Allah swt. berfirman dalam QS. Al-Syu'arā/42:13 


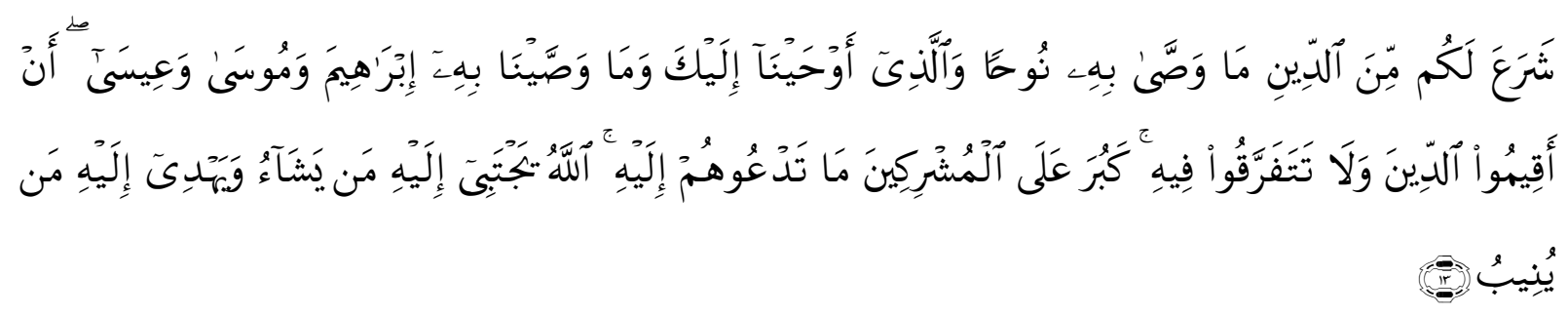

Terjemahnya:

"Dia telah mensyari'atkan bagi kamu tentang agama apa yang telah diwasiatkan-Nya kepada Nuh dan apa yang telah Kami wahyukan kepadamu dan apa yang telah Kami wasiatkan kepada Ibrahim, Musa dan Isa Yaitu: Tegakkanlah agama dan janganlah kamu berpecah belah tentangnya. Amat berat bagi orang-orang musyrik agama yang kamu seru mereka kepadanya. Allah menarik kepada agama itu orang yang dikehendaki-Nya dan memberi petunjuk kepada (agama)-Nya orang yang kembali (kepada-Nya)".

Al-Qur'an sebagai kitab suci, juga sebagai mukjizat yang kekal dan kemukjizatannya itu senantiasa dibuktikan dengan semakin berkembangnya ilmu pengetahuan, melalui pesan-pesan sejarah maupun yang akan terjadi dimasa selanjutnya. Isi kandungannya mulai awal sampai akhir merupakan satu kesatuan yang utuh. Sehingga dalam memahami isi kandungannya, ulama mampu melahirkan berbagai ilmu yang berhubungan dengannya. Meski demikian, tidak dapat dipungkiri pula dalam proses penggalian secara menyeluruh terhadap kitab suci tersebut juga terkadang terdapat berbagai perbedaan. Ibn Katsir dalam Tafsir al-Quran al-Karim, yang dikutip oleh M. Mardan1 membagi kepada empat tingkatan manusia dalam memahami hukum yang termuat di dalam alQur'an. Pertama; cukup jelas bagi sernua orang, kedua; cukup jelas bagi yang dapat berbahasa Arab, ketiga; cukup jelas bagi para ahli, keempat; hanya Allah yang lebih mengetahui maksudnya.

Pada proses penggalian dan pendalaman terhadap kitab suci tersebut ada beberapa hal yang yang berhubungan dengannya antara lain dari segi nuzūl al-Qur'an, asbāb al-nuzūl, jam' al-Qur'an wa tartībuhu, surah-surah makkiyah dan madaniyah, muhkam mutasyābih, nasikh dan mansūkh serta masih banyak lagi ilmu-ilmu lainnya.

Khusus untuk masalah Nāsikh Mansūkh dalam korelasinya dengan al-Qur'an merupakan hal yang sangat panjang untuk dibicarakan, karena melibatkan periwayatan-periwayatan yang jelas atau shahih. Hal ini menuai perbedaan pendapat dari berbagai pakar dan ulama. Muhammad Amin Suma, mengutarakan bahwa di antara kajian Islam tentang hukum yang tetap debatable dan kontroversial adalah masalah naskh, juka dikaitkan dengan kemungkinan adanya nāsikh-mansükh internal ayat alQur'an.2

Pengertian nāsikh mansūkh secara ertimologi dan terminologi merupakan awal perbedaan pemahaman ulama, yang berimplikasi terhadap pendapat penerimaan atau penolakan adanya kemungkinan nāsikh mansūkh dalam al-Qur'an, termasuk di dalamnya penetapan asas untuk menentukan adanya nāsikh mansūkh serta hikmah yang ada terhadap adanya nāsikh mansükh.

1 Mardan, Al-Qur'an; Sebuah Pengantar Memahami al-Qur'an secara Utuh, (Cet. II; Jakarta: Pustaka Mapan, 2009), h. 155.

2 Muhammad Amin Suma, Nask-Mansukh dalam tinjauan Historis, dan Sar'i, (dalam Jurnal al-Insan, Vol. I, No.1, Januari 2005), h. 27. 


\section{PEMBAHASAN}

\section{A. Naskh}

Allah Swt. memerintahkan kepada umat manusia seluruhnya agar memperhatikan dan mempelajari al-Qur'an. Mempelajari al-Qur'an adalah kewajiban dan salah satu pengantar yang dapat mengantarkan seseorang memahami Al-Qur'an. Namun dalam pemahaman terhadap Al-Qur'an dan ilmu-ilmu yang ada di dalamnya sering diwarnai dengan perbedaan. Pembahasan tentang nāsikh mansūkh misalnya, termasuk perdebatan di kalangan ulama bukan tidak beralasan. Asas atau dasar memperbincangkan nāsikh mansūkh tersebut terdapat dalam QS. Al-Nisa/4:82.

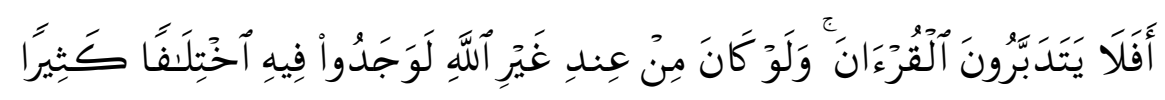

Terjemahnya:

"Maka apakah mereka tidak memperhatikan al-Qur'an, kalau sekiranya al-Qur'an itu bukan dari sisi Allah, tentulah mereka mendapat pertentangan yang banyak di dalamnya".

Ayat ini menyoroti tentang ketentuan yang ada dalam al-Qur'an, bahwa al-Qur'an yang mengandung berbagai jenis pembicaraan serta persoalan, antara satu dengan yang lain terkait dan saling menjelaskan. Pemaknaan yang bisa muncul adalah pertama, dalam al-Qur'an terdapat banyak perbedaan-perbedaan. Sedang yang kedua adalah dalam memaknai al-Qur'an akan muncul berbagai perbedaan/multi tafsir dikalangan ulama. Namun yang lebih tepat menurut penulis adalah pemaknaan yang kedua. Hal ini juga dipertegas oleh Al-Sayuti dan al-Syathibi, bahwa di dalam al-Qur'an tidak terdapat kontradiksi ( ta'aru $\left.^{\prime}\right)$. Metode penafsiran untuk meluruskan pengertian terhadap bagian yang sepintas lalu nampak ada pertentangan. Padahal perlu diketahui bahwa ketika itu sudah dicerna oleh pemikiran manusia maka kebenarannya menjadi suatu yang bersifat normatif.

Jumhur menyepakati bahwa tidak ada yang kontradiksi dalam al-Quran, karena syarat kontradiksi itu antara lain: Persamaan subyek, Obyek, Waktu, dan Syarat.3 Asumsi ini juga dipertegas oleh Manna al-Qaththan, bahwa apa yang cocok untuk satu kaum pada suatu masa mungkin tidak cocok lagi pada suatu masa yang lain. Makki bin Hamusy juga mengungkapkan bahwa khitab yang mengisyaratkan waktu dan batas tertentu. seperti firman Allah Ta'ala dalam QS. AlBaqarah/2: 109

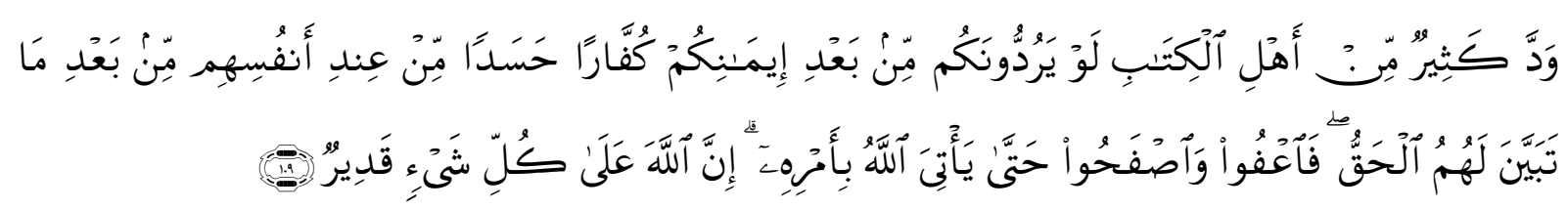

Terjemahnya:

"Sebahagian besar ahli kitab menginginkan agar mereka dapat mengembalikan kamu kepada kekafiran setelah kamu beriman, karena dengki yang (timbul) dari diri mereka sendiri, setelah nyata bagi mereka kebenaran. Maka ma'afkanlah dan biarkanlah mereka, sampai Allah mendatangkan perintah-Nya. Sesungguhnya Allah Maha Kuasa atas segala sesuatu.”

3 Mardan, op. cit., h. 108. 
Olehnya itu, ulama kontemporer sepakat tentang tidak ditemukan perbedaan yang bersifat kontradiktif dalam kandungan ayat-ayat al-Qur'an.4 Sehingga dapat dipahami bahwa sesungguhnya ayat tersebut telah menegaskan antara ayat yang satu dengan ayat yang lain tentu saling terkait, sekaligus mempertegas ketiadaan kontradiksi di dalamnya.

\section{B. Pengertian Naskh (Nāsikh-Mansūkh)}

Secara etimologi:

1. Naskh berasal kata: نسخ - ينسخ - نسخا yang bermakna إز الز (menghilangkan). Misalnya نسخت الريح artinya: “Angin itu menghapuskan/menghilangkan jejak perjalanan.” Sebagaimana dalam QS. AI-Hajj/22: 52 juga disebutkan:

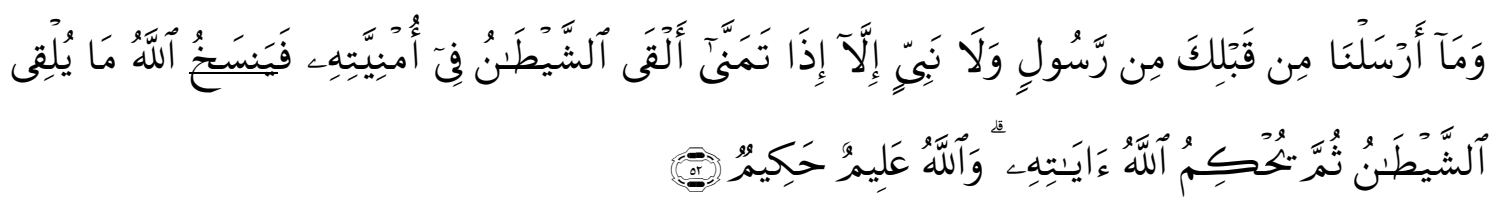

Terjemahnya:

"Dan Kami tidak mengutus sebelum kamu seorang Rasulpun dan tidak (pula) seorang Nabi, melainkan apabila ia mempunyai sesuatu keinginan, syaitanpun memasukkan godaan-godaan terhadap keinginan itu, Allah menghilangkan apa yang dimasukkan oleh syaitan itu, dan Allah menguatkan ayat-ayat- nya. dan Allah Maha mengetahui lagi Maha Bijaksana".

2. Naskh bermakna نقل الثيء من موضع إلي موضع "memindahkan”, misalnya dalam QS. AlJātsiyah/45: 29 yang dimaksud adalah memindahkan (mencatat) amal perbuatan ke dalam catatan amal.5

3. Tabdil, yang diterjemahkan penggantian, seperti termahan yang terdapat dalam, QS. AnNahl/16:101

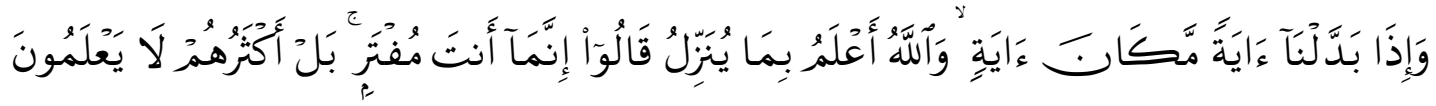

Terjemahnya:

"Dan apabila Kami letakkan suatu ayat di tempat ayat yang lain sebagai penggantinya Padahal Allah lebih mengetahui apa yang diturunkan-Nya, mereka berkata: "Sesungguhnya kamu adalah orang yang mengada-adakan saja. Bahkan kebanyakan mereka tiada mengetahui".

4. Takwil (interpretasi, penakwilan) yang diterjemahkan "memalingkan", dicontohkan dalam ilmu mawāriss, artinya memalingkan pusaka dari seseorang kepada orang lain.

5. Dalam kamus Al-'Ashry terdapat beberapa makna dari نسخ diantaranya:

a. أبطل, ألغى bermakna ; نسخ ; "membatalkan, mencabut"

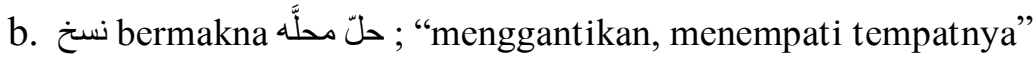

4 Abd. Rahman Jalal al-Din al-Suyuti, al-Itqan fi'Ulum al-Qur'an, (Jus 4. Jilid 2. Cairo; al-Maktabah alTawfiqiyah, ttp), h.27. dan al-Imam al-Syatibi, al-Muwafakat fi Usul al-Syariat (Jilid III, Bairut: Dar-alMa'arif.1975), h.108

5 Mannâ' Khalil al-Qaththân, Mabâhis fi 'Ulum al-Qur'an, (Cet. III; Kairo: Mansyurat al-'Asr al-Hadits, 1973), h. 224. 
c. نسخ bermakna نقل, إكتب ; "menukil, menyalin"

d. نسخ bermakna إستخرج نسخةً ; "meng-copy, membuat duplikat"6

Subhi As-Shalih mengungkapkan bahwa Naskh secara etimologi kadang-kadang bermakna meniadakan, kadang-kadang bermakna penggantian, kadang-kadang bermakna pengalihan, dan adakalanya bermakna pemindahan.7

Pengertian senada juga diungkapkan oleh Mardan bahwa pengertian naskh dari segi etimologi dapat dipakai untuk beberapa pengertian yaitu pembatalan, penghapusan, pemindahan dan pengubahan. Dari pengertian secara etimologi ada diantaranya yang dibakukan menjadi pengertian terminologi.8 Meskipun ada perbedaan pendapat dari para, ulama tentang pengertian secara etimologi, tetapi mereka masih tetap berkisar pada sinonim kata tersebut.9 Perbedaan yang mengundang pro dan kontra di kalangan ulama terjadi ketika mereka memasuki pernbahasan kata ayat yang terdapat pada QS. Al-Baqarah/2: 106.10

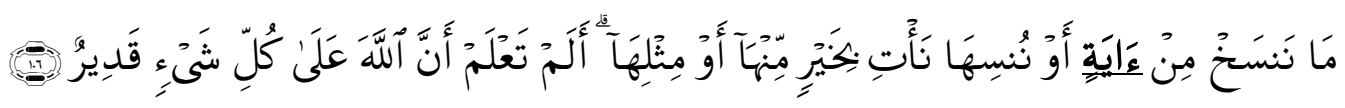

Terjemahnya:

"Ayat mana saja yang Kami nasakhkan atau Kami jadikan (manusia) lupa kepadanya, Kami datangkan yang lebih baik daripadanya atau yang sebanding dengannya. tidakkah kamu mengetahui bahwa Sesungguhnya Allah Maha Kuasa atas segala sesuatu".

Adapun pengertian naskh secara terminologi antara lain:

1. Mengangkat hukum syara' dengan perintah atau khithāb Allah yang datang kemudian dari padanya. 11

2. Mengangkat (menghapuskan) syara dengan dalil hukum syara yang lain.12

Terdapat perbedaan penggunaan istilah yang ada antara ulama mutaqaddimin dengan ulama muta'akhkhirīn hal ini terkait pada sudut pandang masing-masing.13 Sudut pandang itu bersumber dari pemahaman mereka terhadap kata "ayat" yang terdapat dalam surah al-Baqarah/2:106.

Sementara itu Quraish Shihab, menegaskan bahwa antara ulama mutaqaddimin dan muta'akhkhirin tidak sepakat dalam menetapkan pengertian năsikh secara terminologi, hal ini terlihat dari kontroversi yang muncul diantara mereka dalam menetapkan adanya nāsikh dalam al-Qur'an.

Pengertian menurut terminologi ulama mutakaddimīn memberi batasan pengertian nāsikh sebagai dalil syar'i yang ditetapkan kemudian, dijelaskan lebih lanjut tidak hanya bagi ketentuan atau hukum yang mencabut ketentuan atau hukum yang sudah berlaku sebelumnya atau mengubah

6 Atabik Ali dan Ahmad Zuhdi Muhdlor, al-'Ashry; Kamus Kontemporer Arab-Indonesia, (Cet. IX; Yogyakarta: Multi Karya Grafik, t.th.), h. 1908.

7 Subhi As-Shalih, Mahabist fi Ulumil Qur'an, Membahas Ilmu-Ilmu al-Qur'an, (Cet; 10 Jakarta: Pustaka Firdaus), h. 366.

8 Mardan, Al-Qur'an Sebuah Pengantar Memahami al-Qur'an Secara Utuh, (Cet; I Jakarta: Pustaka Mapan, 2009), h. 118.

9 Kamaluddin Marsuki, Ulumul al-Qu'an, (Cet; II Bandung: PT. Remaja Rosdakarya, 1994), h. 133.

10 Kamaluddin Marsuki, Ulumul al-Qu'an, h. 133.

11 Ahmad Syadali, Ahmad Rofi'i, Ulumul Qur'an I, (Cet; II Bandung: CV. Pustaka Setia, 2000), h. 158.

12 Mannâ' Khalil al-Qaththân, h. 326.

13 Kamaluddin Marsuki, Ulumul al-Qu'an, h. 133. 
ketentuan atau hukum yang pertama sebagai pernyataan berakhirnya masa pemberlakuannya, sejauh hukum tersebut tidak dinyatakan berlaku terus menerus.14 Pengertian nāsikh menurut Ulama mutakhkhirīn , nāsikh terbatas hanya untuk ketentuan hukum yang datang kemudian, dengan maksud untuk mencabut atau menyatakan berakhirnya masa pemberlakuan ketentuan hukum yang terdahulu, sehingga ketentuan yang diberlakukan ialah ketentuan yang ditetapkan terakhir dan menggantikan ketentuan yang mendahuluinya.

Berdasarkan beberapa pengertian yang penyusun kutip diatas tergambar bahwa ulama mutaqaddimin memberikan pengertian tentang nāsikh lebih dari satu pengertian, sementara ulama mutaakhkhirin membatasi hanya pada satu pengertian. Jadi dapat dipahami bahwa ulama muta'akhkhirin lebih mempersempit pengertian naskh.

\section{Beberapa Pendapat tentang Naskh dan Dalil Ketetapannya}

Istilah nāsikh yang digunakan dalam ilmu tafsir sering digunakan seiring dengan Istilah mansūkh, Kalau nāsikh diartikan sebagai sesuatu yang membatalkan, menghapus, memindahkan, maka mansūkh diartikan sesuatu yang dibatalkan, dihapus, dan dipindahkan.15

Perbedaan pendapat tentang batasan pengertian nāsikh dan mansükh sebelumnya dilanjutkan kepada masalah ada atau tidaknya nāsikh dan mansūkh dalam al-Qur'an. Ulama dalam menanggapi tentang nāsikh dan mansūkh dalam al-Quran terbagi ke dalam beberapa kelompok,

1. Kelompok ulama Muta'akhkhirin

Sebagian besar Ulama yang berada pada periode ini yang menolak adanya nāsikh dan mansūkh dalam pengertian yang umum, yang termasuk dalam kelompok ulama mutaakhkhirīn, diantaranya adalah Abu Muslim al-Asfahani $(322 \mathrm{H})$ yang ditegaskan oleh Imam al-Syekh Muhammad Abduh (1325 H), al-Sayyed Rasyid Ridha (1354 H), Taufiq Shidqi dan al-Khudhary, serta mufassir besar al-Fakhru al-Razy juga cenderung sependapat dengan imam Al-Asfahany.16 Kelompok ini tidak membenarkan adanya nāsikh dan mansūkh dalam arti menghapus ayat, mereka menuduh kelompok yang menetapkan adanya nāsikh dalam al-Qur'an adalah mereka yang berlebih-lebihan dalam menetapkan ayat yang termasuk kelompok ayat yang dimansükh. Kelompok yang menolak memberi komentar bahwa penetapannya dengan cara membagi dua ayat; yang sepotongnya adalah ayat yang mansūkh dan sebagian yang lain adalah nāsikh. Contoh ayat yang digunakan oleh kelompok Abu muslim adalah surah al-Maidah/5:105, tentang perintah Allah untuk menyeru kepada yang ma'ruf dan mencegah kemungkaran yang dijelaskan oleh lbnu Araby bahwa ayat tersebut awaInya nāsikh dan bagian yang lain adalah Mansūkh, kelompok Abu muslim mengatakan bahwa yang dimaksud dengan naskh, ialah takhsis. 17 Menurut Abu Muslim secara

14 Mardan, h. 119.

15 Mardan, h. 19

16 Hasbi Ash Shiddieqy, Sejarah dan Pengantar Ilmu al-Qur'an/Tafsir, (Cet, XIV; Jakarta: PT. Bulan Bintang, 1992), h. 108.

17 Hasbi Ash Shiddieqy, Ilmu-ilmu al-Qur'an; Media-media Pokok dalam Menafsirkan al-Qur'an, (Cet, III; Jakarta: PT Bulan Bintang, 1993), h. 151-152. 
logika nāsikh dapat saja terjadi, tetapi tidak mungkin terjadi menurut syar'a. Sehingga ia menolak sepenuhnya terjadi naskh dalam al-Qur'an berdasarkan firman Allah dalam QS. Fushshilat/41:42

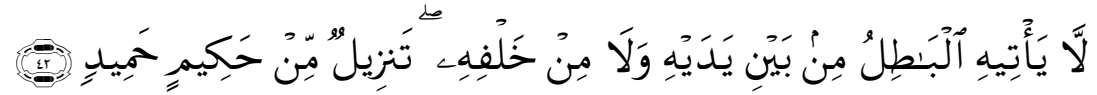

Terjemahnya:

"Yang tidak datang padanya (Al-Qur'an) kebathilan baik dari depan maupun dari belakangnya, yang diturunkan dari Tuhan Yang Mahabijaksana. lagi Maha. Terpuji".

Kelompok Abu Muslim memberikan penjelasan terhadap ayat tersebut bahwa hukumhukum al-Qur'an tidak akan dibatalkan untuk selamanya. Sementara Mannā al-Qattān berpendapat lain bahwa yang dimaksud ayat tersebut adalah adalah bahwa al-Qur'an tidak didahului oleh kitab-kitab yang membatalkannya dan tidak datang pula sesudahnya sesuatu yang membatalkannya. 18

\section{Kelompok Ulama Mutaqaddimīn (Jumhur Ulama)}

Kelompok ini adalah pendapat yang mayoritas. Abu Mansur al-Baghdādy mengungkapkan:19

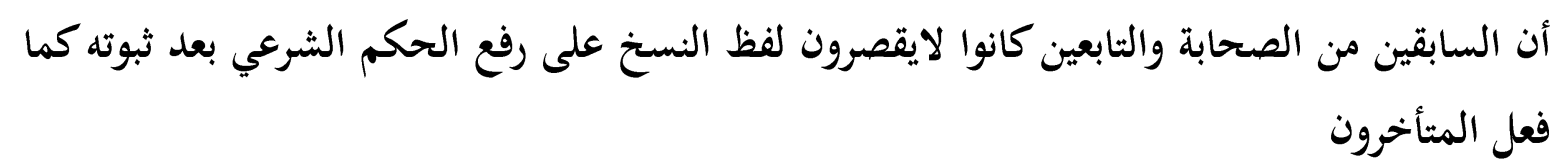

Juga dikatakan bahwa naskh merupakan suatu hal yang rasional (dapat diterima akal) dan telah pula terjadi dalam hukum syara'. Di antara alasan-alasan mereka adalah:

a. Allah Swt. Maha Berkehendak lagi Maha Mengetahui apa yang menjadi maslahat bagi hambaNya. Jadi bisa saja Allah memerintahkan suatu hal pada suatu waktu namun kemudian melarangnya pada waktu yang lain.

b. Beberapa dalil yang membolehkan, diantaranya adalah QS. Al-Nahl/16:10120 QS. AlBaqarah/2:106 dan sebuah hadits shahih dari Ibn Abbas r.a, Umar r.a berkata: "Yang paling paham dan paling menguasai Al-Qur'an di antara kami adalah Ubai. Meski demikian, Ubai pun ditinggalkan sebagian perkataannya, karena ia mengatakan: "Aku tidak akan meninggalkan sedikitpun segala apa yang pernah aku dengar dari Rasulullah saw. Padahal telah turun ayat “... Kami jadikan (manusia) lupa kepadanya... ”21

18 Manna' Khalil al-Qattan, Mabahis fi "Ulumul Qur'an, diterjemahkan oleh MuzakkirAS. Studi IlmuIlmu al-Qur'an, h.333.

19 Al-Baghdady, al-Nasikh wa Al-Mansukh, (Cet. I; Dar al-'Adwa, t.th), h. 27.

20 QS. Al-Nahl/16: 101

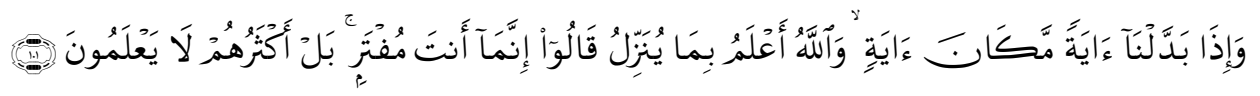

Dan apabila Kami letakkan suatu ayat di tempat ayat yang lain sebagai penggantinya Padahal Allah lebih mengetahui apa yang diturunkan-Nya, mereka berkata: "Sesungguhnya kamu adalah orang yang mengadaadakan saja". bahkan kebanyakan mereka tiada mengetahui.

21 Lihat QS. Al-Baqarah/2: 106 
Beberapa pembagian ulama mutaqaddimin mengenai ayat yang termasuk dalam naskh antara lain :

a. Asy-Syafi'y, An-Nahas $(388 \mathrm{H})$, ayat yang diyakini terdapat naskh di dalamnya menurut AnNahas ada 100 ayat.

b. As-Suyuthy $(911 \mathrm{H})$ menetapkan 20 ayat yang dikategorikan sebagai kelompok ayat nāsikh dan mansükh.

c. Asy-Syaukany $(1250 \mathrm{H})$ menetapkan 8 ayat yang terdapat naskh didalamnya.22 Kelompok ulama ini adalah kelompok yang sepakat menerima ada nāsikh dan mansūkh dalam al-Qur'an didasarkan pada firman Allah dalam QS. al-Baqarah/2:106.23

3. Kelompok orang Yahudi

Kelompok ini tidak mengakui adanya nāsikh, karena nāsikh menurut mereka mengandung konsep al-bada', yaitu nampak jelas, setelah kabur atau tidak jelas. Menurut kelompok ini nāsikh adakalanya tanpa hikmah dan hal ini adalah mustahil bagi Allah.

Mereka juga mengakui bahwa syari'at Nabi Musa menghapus syari'at sebelumnya. Di antara bentuk naskh yang terjadi pada ajaran mereka adalah:

a. Adanya pengharaman sebagian besar binatang atas mereka, padahal sebelumnya dihalalkan.

Hal ini dikisahkan pula dalam QS. Ali Imran/3: 9324, QS. Al-Nisā/4: 16025 dan QS. Al‘An'ām/6:146.26

b. Allah swt. mengharamkan atas Nabi Musa dan Bani Isra'il menikah dengan saudara perempuannya sendiri, padahal jauh sebelumnya Nabi Adam menikahkan anaknya yang bersaudara. Hal ini juga ditegaskan dalam Taurat akan kisah Nabi Adam.

c. Mereka diperintahkan untuk membunuh siapa saja diantara mereka yang menyembah patung anak sapi yang kemudian perintah itu dicabut atau dibatalkan.27

4. Kelompok Syi'ah Rafidah

Kelompok ini berpendapat bahwa konsep al-bada' adalah sesuatu hal yang mungkin terjadi bagi Allah. Untuk memperkuat pandangan mereka, maka mereka mengajukan argumentasi dengan ucapan-ucapan yang dinisbahkan kepada Ali r.a secara dusta dan palsu.28 Bahkan dengan firman Allah swt. dalam QS. Al-Ra'd/13: 39

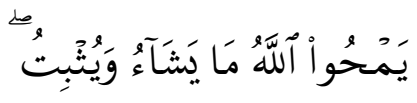

Terjemahnya:

"Allah menghapus apa yang la kehendaki dan menetapkan (apa yang la kehendaki)".

22 Hasbi Ash Shiddieqy, h. 109.

23 QS. Al-Baqarah/2:106

24 QS. Ali Imran/3:93

25 QS. Al-Nisa/4: 160

26 QS. Al-An'am/6: 146

27 Manna Khalil al-Qattan, h. 330-331.

28Manna Khalil al-Qattan, h. 332. 
Kelompok ini memberikan pengertian bahwa Allah menghapus dan menetapkan apa yang ia kehendaki.29 Namun Manna al-Qattan menganggap hal ini adalah pandangan yang sesat karena sesungguhnya Allah menghapuskan sesuatu yang dipandang perlu dihapuskan dan menetapkan penggantinya jika penetapannya mengandung maslahat. Misalnya penghapusan kekafiran atau kemaksiatan seorang hamba yang bertaubat, serta menetapkan iman dan ketaatannya.

Mencermati pendapat kelompok tersebut nampak bahwa kelompok mutaakkhirin menutup ruang untuk hal. itu, sementara kelompok mutakaddimīn membuka ruang yang luas untuk nāsikh namun berusaha untuk mengurangi dengan jalan mengkompromikan ayat-ayat tertentu, sedangkan kelompok yahudi tidak mengakui tetapi menggunakan dalil yang susah untuk diterima, sementara kelompok Syi'ah Rafidah berlebihan dan meluaskan tetapi mengajukan alasan yang dinisbahkan kepada seseorang.

Dari keempat kelompok tersebut di atas dapat disimpulkan bahwa penerimaan terhadap adanya nāsikh dan mansūkh dalam al-Qur'an terbagi kepada dua kubu, yaitu kubu pro dan kontra, kedua kubu ini memberikan alasan masing-masing untuk memperkuat pendapat mereka.

Menurut kelompok yang pro nāsikh yang secara istilah berarti "mencabut berlakunya hukum syara' dengan dalil syara' yang datang kemudian, dianggap oleh pendukung nāsikhmansūkh sangat mungkin dan logis. Kubu ini diwakili oleh Subhi Shalih yang menganalogikan hikmah diturunkannya al-Qur'an secara berangsur-angsur mereka maknai kebijakan Allah di dalam mendidik manusia. Sayyid Abu al-Qasim al-Khu'i, mengemukakan bahwa tidak ada salahnya Allah mencabut suatu hukum dan menggantinya dengan hukum lain sesuai dengan kemaslahatan manusia, yang kemaslahatan itu hanya diketahui oleh Allah. Ringkasnya dalam pandangan pendukungnya, nāsikh bukanlah 'aib bagi Allah yang Maha Sempurna.30

\section{Ruang Lingkup Naskh dalam al-Qur'an}

Terlepas dari kontroversi tentang diterima atau tidak nāsikh dan mansūkh, masalah yang terpenting untuk dibicarakan dalam nāsikh dan mansūkh adalah kawasan penggunaan nāsikh dan mansūkh dalarn upaya interperetasi hukum. Jika upaya untuk mengeluarkan hukum sudah ditempuh sesuai dengan ilmu ushul Fiqhi dan ternyata kontradiksi antara dua ketentuan hukum belum dapat teratasi, pada posisi inilah dimungkinkan adanya nāsikh-mansūkh, atau dilihat dari segi historis menyangkut kedua ketentuan hukum yang kontradiksi. Faktor asbāb al-nuzūl bagi ayat dan asbab alwurud bagi hadits berada pada posisi ini. Dalam kondisi ini nāsikh mansūkh berada pada posisi terakhir dari suatu upaya interpretasi ketentuan hukum.31 Ulama sepakat untuk menetapkan ayat yang dikategorikan kontradiksi dengan syarat yang ketat.

Di antara syarat agar hal itu bisa disebut naskh adalah sebagai berikut:

29 Manna Khalil al-Qattan, h. 332.

30 Kamaluddin Marsuki, h. 136.

31 Mardan, 
1. Hukum yang mansūkh adalah hukum syara'32. Hal ini juga senada dengan Imam al-Sabuni yang mengutip pendapat jumhur ulama yang membatasi bahwa nāsikh mansūkh hanya berkaitan tentang perintah dan larangan.33 Dalam kitab al-Burhan fi Ulum Al-Qur'an disebutkan:

Artinya:

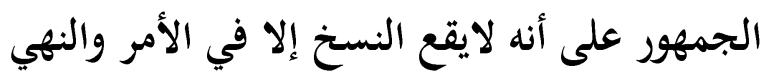

"Jumhur berpendapat bahwasanya tidak terdapat naskh kecuali pada perintah dan larangan".

Bahkan perintah dan larangan itu dalam bentuk khabar (kalimat berita) yang memiliki pesan talāb (perintah) disebut naskh. Sedangkan kalimat berbentuk khabar yang tidak bermakna thalāb, nāsikh tidak terjadi.

2. Dalil yang me-nāsikh adalah khitab syar'i yang datang kemudian; dari khitab yang hukumnya dimansukh.

3. Khitab yang mansūkh hukumnya tidak terikat atau dibatasi dengan waktu tertentu. Sebab jika tidak demikian maka hukum akan berakhir dengan berakhirnya waktu tersebut. Dan yang demikian tidak dinamakan naskh.34

4. Nasik tidak terdapat dalam akhlak dan adab yang diperintahkan dalam Islam35

5. Nāsikh juga tidak terjadi pada Aqidah, seperti: Zat Allah,Sifat Allah, Kitab-kitab Allah, dan khabaryang jelas dan nyata, seperti janji Allah bagi orang yang bertakwa.36

6. Kategori ayat yang tidak tersentuh nāsikh mansūkh yaitu ayat mengenai janji ancaman. Termasuk yang tidak tersentuh nāsikh mansūkh ayat yang berisi cerita tentang berbagai umat.37

7. Sebagian ahli ilmu tidak membenarkan naskh dengan hadits ahad; meskipun itu diriwayatkan oleh perawi yang adil, pendapat mufassir yang awam dan ijtihad para mujtahid tanpa adanya nukilan yang benar dan tanpa ada pertentangan pasti. Namun sebaliknya sebagian yang lain lebih memudahkan/menganggap enteng dengan menerrima atau mencukupkan pada pendapat mufassir atau mujtahid.38 Dan yang dianggap benar menurut kitab al-Itqan adalah kebalikan dari dua pendapat tersebut.

Dari beberapa pendapat tokoh tersebut salah seorang guru besar UIN Alauddin Makassar Mardan, setelah meninjau azas, pengertian, kedudukan, dan kawasan nāsikh -mansūkh, mengemukakan secara lebih luas dan mendetail pensyaratan nāsikh-mansūkh yaitu:

a. Ketentuan hukum yang dicabut, dalam formulasinya tidak berisi keterangan bahwa ketentuan tersebut berlaku sepanjang waktu atau selamanya.

32 Manna Khalil Al-Qattan, h. 327.

33 Juga disepakati Ahmad Syadadi

34 Manna Khalil al-Qattan, h. 327.

35 Ahmad Syadadi, Ahmad Rofi'i. Ulumul Qur'an 1, (Cet. II; Bandung: CV. Pustaka Setia, 2000), h. $160-161$

36 Ahmad Syadadi, h. 160.

37 Kamaluddin Marzuki, op., cit., h. 141.

38 Manna Khalil Al-Qattan, 231. 
b. Ketentuan hukum yang terdapat pada ayat tersebut tidak terkait pada hal yang telah disepakati secara universal tentang kebaikannya atau keburukannya, seperti keadilan adalah hal yang baik sedangkan ketidakadilan adalah hal yang buruk.

c. Ketentuan hukum yang mencabut atau nāsikh, ditetapkan kemudian, karena. menurutnya pada hakikatnya nāsikh adalah mengakhiri pernberlakuan ketentuan hukum yang telah ada sebelumnya.

d. Dalam penelusuran atau penelitian gejala kontradiksi tidak dapat diatasi.39

\section{E. Beberapa Surah dalam Al-Quran yang Berkaitan dengan Naskh}

Syekh Imam Abu al-Hasan Ali bin Ahmad al-Wahidiy al-Nisaburiy mengutip pendapat Abu alQasim dalam kaitannya dengan nāsikh mansūkh, surah dalam al-Quran dibagi menjadi empat kelompok, dengan perincian sebagai berikut :

Pertama, surah yang di dalamnya tidak terdapat ayat naskh jumlahnya sebanyak 43 surah. Masing-masing adalah surah: 40

\begin{tabular}{|c|c|c|}
\hline 1. Al-Fātihah & 16. Al-Nāziat & 31. Al-Ādiyāt \\
\hline 2. Yusuf & 17. Al-Infithār & 32. Al-Qari'ah \\
\hline 3. Yāsin & 18. Al-Muthhaffifin & 33. Al-Takatsur \\
\hline 4. Al-Hujurāt & 19. Al-Insyiqāq & 34. Al-Humazah \\
\hline 5. Al-Rahmān & 20. Al-Burūj & 35. Al-Fil \\
\hline 6. Al- Hadid & 21. Al-Fajr & 36. Al-Qurasy \\
\hline 7. Al-Shaf & 22. Al-Balād & 37. Al-Mā'un’' \\
\hline 8. Al-Jumu'ah & 23. Al-Syams & 38. Al-Kautsar \\
\hline 9. Al-Tahrim & 24. Al-Lail & 39. Al-Nasr \\
\hline 10. Al-Mulk & 25. Al-Dluha & 40. Al-Lahab \\
\hline 11. Al-Hāqqah & 26. Alam nasyirah & 41. Al-Ikhlas \\
\hline 12. Nuh & 27. Al-'Alaq & 42. Al-Falāq \\
\hline 13. Al-Jin & 28. Al-Qadr & 43. Al-Nās \\
\hline
\end{tabular}




\begin{tabular}{|l|l|l|}
\hline 14. Al-Mursalāt & 29. Al-Insiqāk & \\
\hline 15. Al-Naba' & 30. Al-Zalzalah & \\
& & \\
\hline
\end{tabular}

Jika diperhatikan, keempat puluh tiga surah yang disodorkan Abu Al-Qasim sebagai surah yang bebas nāsikh-mansūkh di atas adalah surah yang bersfesifikasi antara lain: Tidak terdapat di dalamnya amar dan nahy. Sementara sebaginya lagi hanya terdapat nahy tanpa amar. Sedangkan sebagiannya hanya terdapat di dalamnya amar tanpa nahy. Nāsikh dan mansūkh memang menurut kubuh pro-nāsikh pun tidak menyentuh ayat-ayat yang membawa pesan amar (perintah) dan nahy (larangan).

Kedua, surah yang di dalamnya terdapat nāsikh tetapi tak terdapat mansūkh. Jumlahnya enam surah, yaitu:41

1. Al-Fath

2. Al-Hasyr

3. Al-Munafikūn

4. Al- Taghabūn

5. Al-Thalaq

6. Al-A'lā

Ketiga, surah yang di dalamnya terdapat ayat-ayat mansūkh, tetapi tidak terdapat padanya nāsikh. Dari segi bilangannya, kelompok surah ini menempati peringkat kedua setelah surah yang tidak kemasukan nāsikh dan tidak pula kemasukan mansūkh, sebanyak 40 surah yaitu:42

\begin{tabular}{|l|l|l|}
\hline 1. Al- An'am & 15. Al-Mu'min & 29. Shab \\
\hline 2. Al- A'raf & 16. Al- Naml & 30. Al-Zumart \\
\hline 3. Yunus & 17. Al-Qashash & 31. Al-Zukhrūf \\
\hline 4. Hūd & 18. Al-Dukhān & 32. Al-Jatsiyah \\
\hline 5. Al-Ra'd & 19. Al-'Ankabūt & 33. Al-Basiqat \\
\hline 6. Al- Hijr & 20. Al-rūm & 34. Al-Ma'rīj \\
\hline 7. Al- Nahl & 21. Luqmān & 35. Nūn \\
\hline 8. Bani Israil & 22. Al-Mashabih & 36. Al-Muddatsir \\
\hline 9. Al-Kahfi & 23. Al-Malaiqah & 37. Al-Qiyāmah \\
\hline
\end{tabular}




\begin{tabular}{|l|l|l|}
\hline 10. Thahā & 24. Al-Shaffāt & 38. Al-Ahqā̄ \\
\hline 11. Al-Insan & 25. Al-Thariq & 39. Al-Qamr \\
\hline 12. Muhammad & 26. Al-Najm & 40. Al-Tin \\
\hline 13. 'Abasa & 27. Al-Ghasiyah & \\
\hline 14. Al-Kafirūn & 28. Al-Imtihān & \\
\hline
\end{tabular}

Keempat, surah yang terdapat nāsikh dan mansūkh berjumlah 25 surah, yaitu:43

\begin{tabular}{|l|l|l|}
\hline 1. Al-Baqarah & 2. Ali Imrān & 3. Al-Nisā \\
\hline 4. Al-Ma'idah & 5. Al-Anfāl & 6. Al-Taubah \\
\hline 7. Ibrahīm & 8. Al-Kahfi & 9. Maryam \\
\hline 10. Al-Anbiya' & 11. Al-Haj & 12. Al-Nur \\
\hline 13. Al-Furqān & 14. Al- Syu'ra' & 15. Al-Ahsab \\
\hline 16. Saba' & 17. Mu'minīn & 18. Al-Syura \\
\hline 19. Al- Dzariyāt & 20. Al-Thur & 21. Mujādilah \\
\hline 22. Al-Muzammīi & 23. Al- Kautsār & 24. Al-Ashr \\
\hline
\end{tabular}

Selain pengelompokan ayat-ayat nāsikh mansūkh dalam al-Qur'an hal yang menjadi perhatian adalah adanya nasikh antara satu syari'at dengan syari'at yang lain, hal ini dapat terjadi, misalnya antara syari'at Nabi Isa dengan Syari'at Nabi Musa, lebih konkritnya antara hukum agama Kristen dan hukum agama Yahudi. Jadi adanya nāsikh mansūkh antara syari'at adalah salah satu bentuk nāsikh, selanjutnya dalam satu syari'at terjadi nāsikh mansūkh antara hukum yang satu dengan hukum yang lain konkritnya, selanjutnya dalam bidang muamalah, hukum keluarga menyangkut persoalan iddah.44 Dalam persoalan adanya nāsikh mansūkh antara satu ayat yang mernuat ketentuan hukum dalam al-Qur'an dengan ayat lain, yang juga mernuat ketentuan hukum dalam soal yang sama, adalah nasihhkh-mansükh antara satu hadis yang memuat ketentuan dalam sunnah dengan hadis lain, yang juga memuat ketentuan hukum dalam soal yang sama, adalah suatu hal yang tidak diperselisihkan. 45

Masalah yang menimbulkan perbedaan pendapat antara para ulama, ialah adanya nāsikhmansūkh silang antara al-Qur'an dengan hadis Nabi Saw. Dalam hubungan ini, jika disimak alasan masing-masing pihak, dapat ditarik satu garis, bahwa faktor utama terjadinya perbedaan pendapat dalam masalah ini adalah pandangan masing-masing tentang kedudukan hirarki al-Qur'an dan sunnah dalam syariat itu sendiri. Karena ada semacam kesepakatan bahwa di dalam nāsikh-mansūkh, kedua 
unsurnya harus sama tingkatannya, kedua unsurnya harus sama tingkatnya, sama nilai, dan sifatnya. Mutawātir dan ahad termasuk faktor yang dipertimbangkan.46 Alur pikiran seperti ini terdapat juga dikalangaan para ahli hukum, bahwa sesuatu peraturan hukum tidak dapat dicabut dengan peraturan hukum lain yang lebih rendah tingkatannya, demikian juga lembaga yang memproduk peraturan hukum itu, hal ini juga menjadi faktor pertimbangan. 47

\section{F. Jenis dan Contoh Naskh}

Terdapat beberapa jenis nask $h$ beserta contohnya, diantaranya:

1. Naskh al-Qur'an dengan al-Qur'an

Contoh:

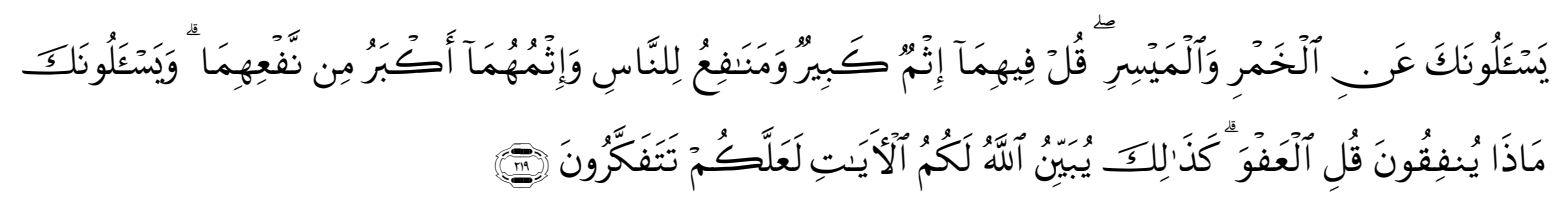

Terjemahnya:

"Mereka bertanya kepadamu tentang khamar dan judi. Katakanlah: "Pada keduanya terdapat dosa yang besar dan beberapa manfaat bagi manusia, tetapi dosa keduanya lebih besar dari manfaatnya". dan mereka bertanya kepadamu apa yang mereka nafkahkan. Katakanlah: "Yang lebih dari keperluan." Demikianlah Allah menerangkan ayat-ayat-Nya kepadamu supaya kamu berfikir".48

Pada ayat lain yang turun selanjutnya:49

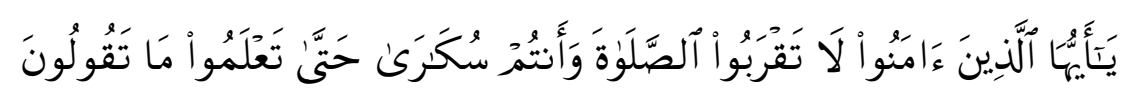

Terjemahnya:

"Hai orang-orang yang beriman, janganlah kamu shalat, sedang kamu dalam keadaan mabuk, sehingga kamu mengerti apa yang kamu ucapkan".

Kemudian selanjutnya Allah berfirman:50

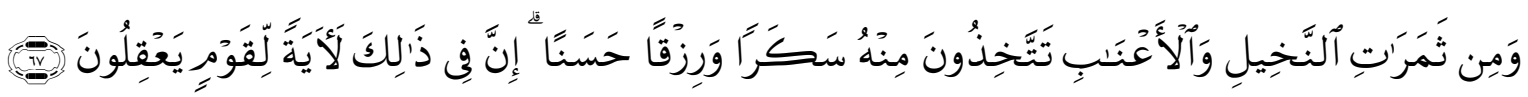

Terjemahnya:

"Dan dari buah korma dan anggur, kamu buat minimuman yang memabukkan dan rezki yang baik. Sesunggguhnya pada yang demikian itu benar-benar terdapat tanda (kebesaran Allah) bagi orang yang memikirkan".

Beberapa ayat di atas kemudian di-naskh oleh Allah swt. akan kebolehan minum khamar dan manfaat yang ada pada minuman tersebut. Allah 'azza wa jalla menegaskan dalam firmanNya pada QS. Al-Māidah/5:90

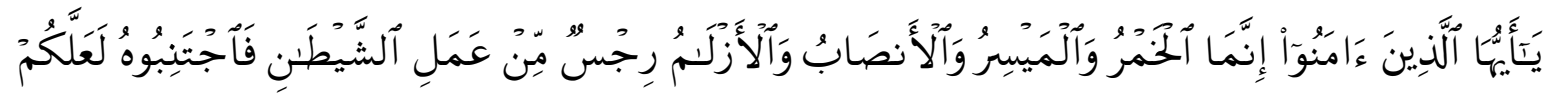


Terjemahnya:

"Hai orang-orang yang beriman, Sesungguhnya (meminum) khamar, berjudi, (berkorban untuk) berhala, mengundi nasib dengan panah, adalah termasuk perbuatan syaitan. Maka jauhilah perbuatan-perbuatan itu agar kamu mendapat keberunt ungan”.

Contoh naskh diatas sebagaimana yang dijelaskan dalam kitab Al-Nāsikh wa Al-Mansūkh karangan Abu Mansyur Al-Baghdady.

\section{Naskh al-Qur'an dengan al-Sunnah}

Pada bagian ini jumhur ulama berpendapat al-Qur'an tidak boleh di-nāsikh oleh hadits ahad. Sedangkan naskh Al-Qur'an dengan hadits mutawatir dibolehkan oleh Imam Malik, Imam Ahmad dan Abu Hanifah dalam satu riwayat. Mereka beralasan Hadits dan Al-Qur'an adalah wahyu.51 Sebagaimana dalam QS. al-Najm/53:3-452 dan QS. al-Nahl/16:44.53

Sedangkan di sisi lain Imam Syafi'i dan Ahli Zahir menolak naskh Al-Qur'an dengan Sunnah. Berdasarkan pada firman Allah dalam QS. Al-Baqarah/2: 106, dimana hadits tidak sebanding dengan Al-Qur’an.54 Dengan kata lain: 555 “al-Qur’an tidak dinaskh kecuali dengan al-Qur'an".

Faktor utama terjadinya perbedaan pendapat dalam masalah ini adalah pandangan masingmasing tentang kedudukan hirarki Al-Qur'an dan sunnah dalam syariat itu sendiri

3. Naskh al-Sunnah dengan al-Qur'an

Hal ini dibolehkan oleh jumhur ulama. Misalnya tentang masalah menghadap ke Baitul Maqdis56 yang ditetapkan dengan sunnah kemudian di-naskh oleh QS. Al-Baqarah/2:144

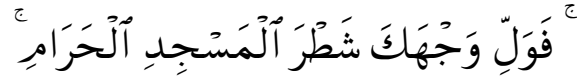

Terjemahnya:

"Palingkanlah mukamu ke arah Masjidil Haram".

Namun naskh versi ini juga ditolak oleh Imam Syafi'i. Menurutnya apa saja yang ditetapkan oleh al-Sunnah tentu didukung oleh al-Qur'an, begitupun sebaliknya. Hal ini karena keduanya harus senantiasa sejalan dan tidak bertentangan.57 Penulis memahami bahwa baik naskh al-Qur'an dengan Sunnah ataupun sebaliknya, tidak dibenarkan oleh Syafi'i.

4. Naskh al-Sunnah dengan al-Sunnah

Pada bentuk naskh seperti ini terdapat empat bentuk, yaitu pertama; naskh hadits mutawatir dengan yang mutawatir, kedua; naskh hadits ahad dengan hadits ahad, ketiga; naskh hadits ahad dengan hadits mutawatir, keempat; naskh hadits mutawatir dengan hadits ahad.

51 Manna Al-Qattan, h. 335.

52 QS. An-Najm/53:3-4

53 QS. An-Nahl/16:44

54 Manna Al-Qattan, h. 335.

55 Al-Zarqasy, Al-Burhan fi Ulum Al-Qur'an.

56 Kaum Muslimin sesudah hijrah ke Madinah berkiblat ke arah Bait al-Muqaddas, sekitar enam bulan kemudian berubah ke arah Bait al-Haram.

57 Manna Al-Qattan. 
Untuk tiga bentuk naskh yang pertama masih dibolehkan, namun untuk naskh yang keempat juga ada sebagian yang menolak dengan menganalogikan kepada naskh al-Qur'an.

Contoh dari sunnah misaInya, hukum ziarah kubur. Di dalam hadis Nabi saw. Disebutkan bahwa "Pernah aku melarang kalian melakukan ziarah kubur, sekarang lakukanlah " (Lihat Jami' al-Sahih oleh Imam Muslim).58

Kelompok pendukung nāsikh mansūkh, melanjutkan pembahasan ulumul Qur'an mereka membagi nāsikh mansūkh menjadi tiga kategori.

Kategori pertama; ayat yang bacaan dan hukumnya di-nāsikh, contohnya sebuah riwayat alBukhari dan Muslim hadis dari 'Aisyah ra. tentang dua anak yang berlainan ibu sudah dianggap bersaudara apabila salah seorang di antara keduanya menyusu kepada ibu salah seorang di antara mereka sebanyak sepuluh isapan ini kemudian di-nāsikh menjadi lima isapan, ayat tentang sepuluh atau lima isapan. Dalam menyusu kepada seorang ibu sekarang sudah tidak terdapat dalam mushaf al-Qur'an (mushaf Usmani) karena baik bacaan maupun hukumnya telah dinaskh.59 Namun dalam peristiwa ini, Qadi Abu Bakar menceritakan dalam al-Intisār bahwa terdapat suatu kaum yang mengingkari naskh semacam ini dengan alasan ada khabar yang berkaitan dengannya. Tetapi penolakan itu tidak dibenarkan khabar ahad tidak boleh dijadikan hujjah.60

Kategori kedua; ayat yang bacaannya di-nāsikh, sedangkan hukumnya tidak. Contohnya ayat tentang hukum rajam kepada orang tua yang berzina. Pada awalnya ayat rajam ini terbilang ayat al-Qur'an, kemudian bacaannya di-nāsikh, sementara hukumnya tetap berlaku. Ayat yang dinyatakan mansūkh bacaannya sementara hukumnya tetap berlaku adalah:

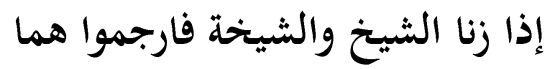

Artinya:

"Jika seorang pria tua dan wanita tua berbuat zina, maka rajamlah keduanya".

Kisah tentang ayat perlakuan terhadapa orang tua berzina di atas dicontohkan oleh Amir Abd. Aziz, berdasarkan riwayat dari Ubai bin Ka'ab.61

Kategori ketiga; ayat yang bacaannya berlaku, sedang hukumnya di-nāsikh. Misalnya mengenai QS. Al-Baqarah/2: 24062 tentang masa iddah seorang isteri selama satu tahun.

\section{G. Hikmah adanya Naskh dalam al-Qur'an}

Sudah menjadi ketentuan Allah, segala sesuatu yang terjadi dan ada dalam kehidupan kita tidak terlepas dari hikmah yang terdapat di dalamnya. Sebelum menguraikan hikmah adanya nāsikh dan mansūkh perlu dikernukakan pengertian hikmah, karena dalarn kamus besar bahasa Indonesia hikmah mempunyai beberapa arti, antara lain: kebijaksanaan, sakti, kesaktian, manfaat, arti atau

58 Mardan

59 Kamaluddin Marsuki, h.137.

60 Manna al-Qattan, h. 336-337.

61 Kamaluddin Marsuki, h. 137.

62 QS. Al-Baqarah/2: 240 
makna yang dalam.63 Dalam membahas hikmah nāsikh-mansūkh dalam al-Qur'an arti yang rasional digunakan adalah: "manfaat atau makna yang dalam".

Adanya nāsikh mansūkh tidak dapat dipisahkan dari sifat nuzūl-nya Al-Qur'an serta tujuan yang ingin dicapai dari sifat nuzūl tersebut khususnya dalam hukum. Syekh al-Qasimi berkata proses tadarrüj (bertahap) adalah sebuah proses yang alami dan wajar terhadap hukum Allah sebagai upaya untuk memberi kesempatan kepada manusia untuk menyesuaikan dan belajar untuk memudahkan manusia menerapkan hukum Allah.64 Dalam literatur yang sama, Imam al-Maragi mengemukakan hikmah nāsikh mansūkh adalah untuk kemaslahatan umat manusia. Sementara Manna al-Qattan menguraikan hikmah nāsikh mansūkh dalam al-Quran sebagai berikut:

1. Memelihara kepentingan hamba.

2. Perkembangan tasyri' menuju tingkat sempurnaan sesuai dengan perkembangan dakwah dan perkembangan kondisi umat manusia.

3. Cobaan atau ujian bagi orang mukalläf untuk mengikutinya atau tidak.

4. Menghendaki kebaikan dan kemudahan. bagi manusia. Karena bila nāsikh beralih kepada hal yang lebih berat maka tentu di dalamnya terdapat tambahan pahala, dan sekiranya beralih ke hal yang lebih ringan maka tentu nāsikh mengandung kemudahan dan keringanan.65

Sementara Imam al-Qurthubi mengemukakan bahwa pengetahuan tentang nāsikh mansūkh sangat besar manfaatnya, karena dapat mengarahkan manusia mengetahui hukum-hukum yang berkaitan dengan halal dan haram.66 Juga membantu dalam menafsirkan dan memberikan fatwa kepada umat Islam dengan berpedoman kepada peristiwa naskh dalam al-Qur'an.

\section{KESIMPULAN}

1. Nāsikh dalam Ulumul Qur'an diartikan sebagai sesuatu yang membatalkan, menghapus, memindahkan, maka mansūkh diartikan sesuatu yang dibatalkan, dihapus dan dipindahkan. Sedang pengertian secara terminologi adalah mengangkatkan hukum syara' dengan perintah atau khitab Allah yang datang kemudian dari padanya.

2. Kesepakatan ulama tafsir dan ularna ushul tentang ketentuan pembatasan penerapan nāsikh mansūkh, yaitu: nāsikh hanya terjadi pada ayat amar dan nahy, ayat yang tidak tersentuh nāsikh mansūkh yaitu ayat menggenai aqidah dan sifat-sifat-Nya, tentang janji dan ancaman. Dan ayat tidak bisa di-naskh dengan ra'y, ijtihad dan tafsiran tanpa menukil dalil dan penggalian secara history.

3. Masalah nāsikh-mansūkh bukan suatu hal yang berdiri sendiri, tetapi merupakan bagian yang berada dalam disiplin ilmu tafsir dan ilmu Ușul Fikih, sehingga merupakan hal yang teknis dengan

63 Kamus Besar Bahasa Indonesia, (Cet. III; Jakarta: Balai Pustaka), h. 307.

64 Mardan, h. 128.

65 Manna Khalil al-Qattan, h.240.

66 Ahmad Syadali, Ahmad Rofi'i, h. 167. 
batasan pengertian yang sudah baku. Sedang hikmah adanya nāsikh mansūkh untuk kemaslahatan umat manusia.

\section{DAFTAR PUSTAKA}

Ali, Atabik dan Ahmad Zuhdi Muhdlor, al-'Ashry; Kamus Kontemporer Arab-Indonesia. Cet. IX; Yogyakarta: Multi Karya Grafik, t.th.

Artmanda, Frista W. Kamus Lengkap Bahasa Indonesia. Jornbang: Lintas Pustaka

Bisri Abid, A. Fatah Munawwir. Kamus Indoneria-Arab; Arab-Indonesia. Cet. I Surabaya: Pustaka Progresif, 1999.

Mardan. Al-Qur'an; Sebuah Pengantar Memahami al-Qur'an Secara Utuh. Cet. XI; Jakarta: Pustaka Mapan, 2009.

Marsuki, Kamaluddin. Ulum al-Quran. Cet. II; Bandung: PT Remaja Rosdakarya, 1994.

Al-Qattan, Manna' Khalil. Mabahis fi ulumu al- Quran. Cet. II; Mansyurat al-'Asr al-Hadis, t.th. . Mabahis fi Uumul Qur'an, diterjemahkan oleh Mudzakir AS. Studi Ilmu-ilmu Qur'an . Cet. XII; Bogor: Pustaka Litera AntarNusa, 2009.

Al-Shalih, Subhi. Mahabits fi Ulum al-Qur'an; Membahas ilmu-ilmu Al- Quran. Cet; 10 Jakarta: Pustaka Firdaus

Shiddiqy, Hasbi. Ilmu-ilmu al-Quran; Media-media Pokok dalam Menafsirkan al-Quran. Cet. III; Jakarta: Pt Bulan Bintang, 1993. . Sejarah dan Pengantar Ilmu al-Quran. Cet. XIV; Jakarta: PT. Bulan Bintang, 1992.

Suma, Muhammad Amin. Jurnal al-Insan; Nasikh-Mansukh dalam Tinjauan Historis dan Syar'i. Vol. I; No.1; Januari 2005.

Al-Suyuti, Abd. Rahman Jalal al-Din. al-Itqan fi'Ulum al-Qur'an. Juz IV; Jilid II; Cairo: alMaktabah al-Tawfiqiyah, ttp.

Al-Syadadi, Ahmad dan Ahmad Rofi'i. Ulumul Qur'an 1. Cet. II; Bandung: CV. Pustaka Setia, 2000. Al-Syatibi, al-Imam. al-Muwafakat fi Usul al-Syariat. Jilid III, Beirut: Dar-al-Ma'arif, 1975.

Al-Zarkasyi, Badruddin Muhammad bin Abdullah. Al-Burhān fi Ulum Al-Qur'an Kairo: Dar alTurats, t.th. 